This item was submitted to Loughborough's Research Repository by the author.

Items in Figshare are protected by copyright, with all rights reserved, unless otherwise indicated.

\title{
Klinefelter syndrome, insulin resistance, metabolic syndrome, and diabetes: review of literature and clinical perspectives
}

PLEASE CITE THE PUBLISHED VERSION

https://doi.org/10.1007/s12020-018-1584-6

\section{PUBLISHER}

(C) Springer

VERSION

AM (Accepted Manuscript)

\section{PUBLISHER STATEMENT}

This work is made available according to the conditions of the Creative Commons Attribution-NonCommercialNoDerivatives 4.0 International (CC BY-NC-ND 4.0) licence. Full details of this licence are available at: https://creativecommons.org/licenses/by-nc-nd/4.0/

\section{LICENCE}

CC BY-NC-ND 4.0

\section{REPOSITORY RECORD}

Salzano, Andrea, Roberta D'Assante, Liam Heaney, Federica Monaco, Giuseppe Rengo, Pietro Valente, Daniela Pasquali, et al.. 2019. "Klinefelter Syndrome, Insulin Resistance, Metabolic Syndrome, and Diabetes: Review of Literature and Clinical Perspectives". figshare. https://hdl.handle.net/2134/33320. 


\section{Klinefelter syndrome, insulin resistance, metabolic syndrome and diabetes. \\ Review of literature and clinical perspectives.}

Andrea Salzano*1,2, Roberta D'Assante*3, Liam M. Heaney ${ }^{2}$, Federica Monaco ${ }^{1}$, Giuseppe Rengo ${ }^{1}$, Pietro Valente ${ }^{1}$, Daniela Pasquali ${ }^{4}$, Eduardo Bossone $^{5}$; Daniele Gianfrilli ${ }^{6}$, Andrea Lenzi ${ }^{6}$, Antonio Cittadini $^{1}$, Alberto M. Marra ${ }^{3}$, Raffaele Napoli ${ }^{1}$.

*These authors equally contributed

${ }^{I}$ Department of Translational Medical Sciences, Federico II University School of Medicine, Naples, Italy

${ }^{2}$ Department of Cardiovascular Sciences and NIHR Leicester Biomedical Research Centre, University of Leicester, Glenfield Hospital, Leicester, UK,

${ }^{3}$ IRCCS S.D.N., Via Gianturco 113, 80143, Naples, Italy

${ }^{4}$ Department of Neurological, Metabolic, and Geriatric Science, Endocrinology Unit, University of Campania "Luigi Vanvitelli", Caserta, Italy

${ }^{5}$ Department of Cardiology and Cardiac Surgery, University Hospital "Scuola Medica Salernitana”, Salerno, Italy

${ }^{6}$ Department of Experimental Medicine, Sapienza University of Rome, Rome, Italy

Keywords: Klinefelter syndrome, Diabetes mellitus, Metabolic syndrome, Insulin resistance, Testosterone therapy, Cardiovascular diseases, Cardiovascular risk factor

\section{Corresponding Author:}

Prof. Antonio Cittadini

Department of Translational Medical Sciences

Federico II University School of Medicine

Via Pansini 5,

80131 Naples, Italy.

E-mail address: antonio.cittadini@unina.it 


\begin{abstract}
Klinefelter syndrome (KS), the most frequent chromosomic abnormality in males, is associated with hypergonadotropic hypogonadism and an increased risk of cardiovascular diseases (CVD). The mechanisms involved in increasing risk of cardiovascular morbidity and mortality are not completely understood. Insulin resistance, metabolic syndrome, and type 2 diabetes are more frequently diagnosed in KS than in the general population; however, the contribution of hypogonadism to metabolic derangement is highly controversial. Whether this dangerous combination of risk factors fully explains the CVD burden of KS patients remains unclear. In addition, testosterone replacement therapy only exerts a marginal action on the CVD system. This review summaries the current understandings of the complex relationship between KS, metabolic syndrome and cardiovascular risk in order to plan future studies and improve current strategies to reduce mortality in this high-risk population. Since fat accumulation and distribution seem to play a relevant role in triggering metabolic abnormalities, an early diagnosis and a tailored intervention strategy with drugs aimed at targeting excessive visceral fat deposition appear necessary in patients with KS.
\end{abstract}




\section{Introduction}

Klinefelter syndrome (KS) is an aneuploidy characterized by a supernumerary $\mathrm{X}$ chromosome and hypergonadotropic hypogonadism [1]. The estimated prevalence of 1 case per 660 newborns, increasing to 3-4\% among infertile men and 10-12\% in azoospermic men, makes $\mathrm{KS}$ the most common abnormality of sex chromosomes [2-4]. Clinical features of the syndrome vary broadly [5-9], but the hallmark of KS remains infertility [5] with most of cases remaining undiagnosed until the attempt to conceive [10]. While about $85 \%$ of KS is due to one single additional X chromosome (47,XXY), the remaining $15 \%$ displays multiple aneuploidies (48,XXXY; 48,XXYY; 49,XXXXY) causing development of a much more complex phenotype [11]. This includes mental retardation that is no longer considered a feature of classical KS [12]. For this reason, aneuploidies with more than 47 chromosomes should be considered a distinct condition $[5,11]$.

Compared to the general population, patients with KS show higher all-cause and cardiovascular disease (CVD) mortality [13-17]. Data from recent large registry-based studies reported a significant increase in mortality risk by $40 \%$ (hazard ratio (HR) for all-cause mortality $=$ 1.40; HR cardiovascular mortality $=1.41)[14]$ with a standardized mortality ratio $(\mathrm{SMR})$ of 1.5 [15], corresponding to a significantly reduced median survival of 2.1 years. Patients with KS are more frequently insulin resistant, obese and prone to develop type 2 diabetes mellitus (T2D) $[18,19]$, a condition considered a CVD equivalent. The onset of T2D in patients with KS is a turning point in worsening of the CVD risk profile. With this in mind, we explored and reviewed the relationship between KS and metabolic abnormalities, focusing on diabetes mellitus and its implications on the increased CVD mortality observed in KS patients.

\section{Insulin-resistance and metabolic syndrome in Klinefelter syndrome}

According to the National Cholesterol Education Program - Adult Treatment Panel III (NCEP- ATP III) criteria [20], metabolic syndrome (MS) clusters multiple CVD risk factors. In 
2005, the International Diabetes Federation (IDF) reviewed these criteria which lead to an increased estimated prevalence of MS [21]. These criteria have now been reconciled in a joint interim statement to more precisely characterize MS [22]. Furthermore, a definition of pediatric MS, designed to be closely analogous to ATP III, was described by de Ferranti et al. in 2004 [23].

As summarized in Table I, the prevalence of MS in patients with KS appears higher than in the general population, with data suggesting a 4-fold higher prevalence of MS in untreated KS than controls (46\% vs 10\%) [24]. In the same study, patients with KS presented with insulin resistance (IR - measured by the HOMA index), low androgens and low HDL cholesterol concentrations. KS was consistently associated with increased total body fat, however surprisingly, testosterone replacement therapy (TRT) did not modify fat tissue distribution or insulin sensitivity (IS) (Table I and Fig.1). Similar findings in respect to lipid and testosterone levels and MS were described in a subsequent study [25]. More than one third of patients with KS were identified as IR when tested by the euglycemic hyperinsulinemic clamp [26]. In this elegant study, serum testosterone levels were independently associated with insulin-mediated whole body glucose uptake, suggesting hypogonadism might be responsible for IR in KS patients [26]. In a smaller study, Pei and colleagues confirmed that IR, measured by insulin area under the curve (AUC) during a 75-gr oral glucose load and insulin suppression test, was constantly elevated in patients with KS [27]. Interestingly, plasma glucose at the steady state was inversely correlated to testosterone levels, again pointing toward a role for androgens in the IR of KS. In a study performed by ourselves, we described a prevalence of $49 \%$ for MS in 69 untreated KS patients, compared to $10 \%$ among controls [28]. In the 48 patients prescribed TRT, the prevalence of MS during the 3-year follow-up period was unaltered and remained higher than that observed in a group of 21 men with hypogonadotropic hypogonadism treated with testosterone [28]. These data indicate that KS patients are more insulin resistant, have increased body fat and lower levels of HDL, and show an increased prevalence of MS when compared to a control population. Also, circulating testosterone appears related to IS, however, the effect of TRT does not reverse MS. In the general population 
and in experimental models, a clear bidirectional relationship between testosterone and IS exists [29-31]. Low testosterone levels are associated with increased IR [31] and the onset of IR may influence testosterone levels [32,33] (Fig. 1). Treatment of hypogonadal men with testosterone improves metabolic risk factors and IR in some, but not all studies [34]. Compared to other types of hypogonadism, TRT has shown to not improve body fat distribution or IR in KS [24,28], suggesting either a possible" hormonal resistance", consistent with the accompanying elevated LH [10], an increased aromatization [35], or alternatively, that the androgens are not involved in the metabolic impairment of KS. The chromosomal abnormality may act through additional mechanisms in triggering IR, differential body fat distribution and MS (Fig. 1), despite inactivation of the extra X chromosome. From this point of view, the study of prepubertal adolescents with KS offers an important opportunity. Although they carry the chromosomal abnormality of the syndrome these patients have similar, prepubertal, circulating testosterone and gonadotropin plasma levels to agematched healthy controls. Therefore, the independent, non-hormonal, role of chromosomal abnormalities can be better ascertained at this age $[10,36]$. In a group of 89 boys between 4 and 12 years, $30 \%$ had a waist circumference $>90^{\text {th }}$ percentile (vs $21 \%$ matched controls), $24 \%$ were insulin resistant and 7\% had three age-matched criteria for the diagnosing MS [37]. In a more recent cohort of 93 pre-pubertal boys with KS [38], $80 \%$ had $\geq 1$ feature of MS and $11 \%$ had $\geq 3$ features of MS. In the same cohort of patients, authors performed a 2-year double-blind placebocontrolled trial of oral oxandrolone (Ox) [39]. This showed a modest improvement in some features of MS (systolic BP, fasting blood glucose, and triglycerides) and in body composition although, after adjusting for age and baseline measures, the only significant change was a reduction of triglycerides. In particular, these changes were more strongly associated within the subgroup of patients who remained prepubertal throughout the 2-year study. In addition, the treatment did result in bone age advancement and lowering of HDL cholesterol. Of note, total body fat, assessed by bioelectrical impedance analysis, was found higher in infants and adolescents with KS, independently of BMI, age, and testosterone concentration. Thus, KS patients 
seem to display an accumulation of truncal body fat and lower lean body mass (28). Iwatsuki et al. demonstrated that LH and FSH, but not testosterone, inversely correlate with BMI in KS but not in men without KS [40]. Aksglaede et al. comparing eighteen untreated and six testosterone-treated KS boys to a group of normal aged-matched controls, found an increased fat body mass, but normal lean body mass, in patients with KS [41]. Overall, these data suggest that an unfavorable metabolic profile is already present in children with $\mathrm{KS}$, although testosterone levels are not different from their healthy peers.

Bojesen et al. showed that in patients with KS, as for the general population, truncal body fat is associated with IR [22]. Interestingly, when metabolic data from patients with KS were adjusted for truncal body fat, the correlation with hypogonadism was lost, suggesting that the effects of androgens on IS was mediated by fat distribution. Recently, in a group of ten obese KS patients with T2D and erectile dysfunction (ED), the addition of metformin and liraglutide induced weight loss and improved erectile function in the patients in which TRT alone was insufficient to achieve serum $\mathrm{T}$ levels in the range of healthy men. Furthermore, the patients were able to reach glycemic targets and to lower weight, leading to a considerable improvement of ED [42].

Recently, a prevalence of obesity in Korean men with KS of $42.6 \%$ was reported, with testosterone level as an independent risk factor for obesity and hyperglycemia [43]. On the other hand, obesity in KS is not just a bystander, since only KS patients with obesity have a high incidence of hyperglycemia, low testosterone level, and elevated LH and FSH levels [44].

A very intriguing relationship exists between KS, MS and the increased risk of thromboembolic disease $[18,43,45,46]$. MS is associated with a low-grade chronic inflammatory status. Recently in a cohort of 26 testosterone treated KS patients, serum levels of C-C motif chemokine ligand 2 (CCL2), the major chemokine released by the monocytes and macrophages and associated with IR, along with prevalence of MS (50\%) and IR were higher than in controls. However, when the group of patients was divided according to the presence of MS, hormone concentrations, adiponectin, CCL2, and CXC motif chemokine 10 (CXCL10) levels were similar. 
Therefore, the effects on CCL2 circulating plasma levels seen in KS were not mediated by MS or body fat distribution, rather to other putative mechanisms operating in KS itself. In fact, the observation that in patients with KS testosterone correlated positively with CCL2 contrasts with in vitro data where testosterone reduces the secretion of several cytokines and chemokines, including CCL2, from peripheral blood mononuclear cells [47]. Consistently, when adult men are acutely deprived of testosterone, CCL2 levels increase. These data suggest that a proinflammatory status in KS may also account for some dysfunction of Leydig cells $[47,48]$ and that macrophage infiltration into an expanded adipose tissue might be involved in the development of MS in KS [49].

\section{Diabetes mellitus in Klinefelter syndrome}

Type 1 diabetes mellitus (T1D) accounts for between 5 and $10 \%$ of all diabetes cases and is due to autoimmune destruction of the pancreatic beta-cells [50]. Autoimmunity is also frequent in KS. Interestingly, a recent study demonstrated that immunoreactivity directed against diabetesspecific autoantigens was significantly increased in KS (8.2\%) than matched controls, but the autoantibody endocrine profile of untreated and treated KS patients was not different [51]. Bojesen et al. [13] reported a 2.5-fold increased risk of T1D in KS when compared to the general population. Since the first study evaluating the prevalence of T2D and KS performed by Langeron et al. in 1958 [52], many reports [53-66] have documented the association of KS with T2D (Table II). An abnormal oral glucose tolerance test can be detected in more than one third of KS patients [56], leading to the suggestion of considering KS a "prediabetes" [57]. The prevalence of overt diabetes in $\mathrm{KS}$ is estimated higher than $10 \%$ in various studies [59-65,67]. Interestingly, the prevalence of diabetes is increased also in parents of siblings with KS [61], suggesting a familiar cluster of the metabolic abnormalities. Of interest is the observation that the prevalence of diabetes is even higher (up to $57 \%$ ) in patients with the more severe karyotypes (48, or 49 chromosomes), pointing to an additive role of the supernumerary X-chromosomes in the onset of T2D in KS [62]. Our group reported a prevalence of diabetes slightly higher than in the general population [28]. 
Recently, Han et al found a prevalence of $26 \%$ of "prediabetes" and of $13 \%$ of diabetes in 375

Korean KS patients. Despite no difference observed for the prevalence of diabetes between obese and non-obese KS patients, prediabetes was more frequent in the obese KS group [43].

The course of diabetes in patients with KS has some peculiarities compared to the general population. In particular, KS patients develop the disease earlier in life (onset around 30 years) and with an associated BMI lower than what is usually observed in non-KS patients with T2D. Finally, insulin treatment appears less effective in achieving metabolic control [60], but compliance might be a confounding issue. As for MS, TRT does not halt the onset of diabetes in KS, nor changes its severity [45]. Data from large registry-based studies showed a HR of 2.21 for T1D and 3.71 for T2D in KS [13-17]. In a cohort of 781 Danish KS patients, a $60 \%$ increase in the risk of death due to T2D was reported [13]. However, such reported risk might well be underestimated, since T2D is not usually recorded as a primary cause of death. Swerdlow et al. extracted data from a cohort of 4806 UK-based patients with KS diagnosed between 1959 and 2002 [15]. The authors calculated the SMR related to diabetes at 5.8 and showed that the contribution of diabetes as the cause of death in this population increased with age. In addition, no differences were found when the classic XXY karyotype was compared with other chorotypes or mosaic, although abnormal glucose tolerance was more frequently detected in classical KS [57].

The clinical response to TRT might be influenced by the polymorphism of the gene encoding for the androgen receptor on the $\mathrm{X}$ chromosome. A certain number of CAG repeats (CAGn) characterizes this gene and the number of CAGn is inversely associated with androgen sensitivity: the higher the CAGn, the lower the sensitivity to androgens, suggesting a possible role in the clinical response to testosterone therapy in KS [67]. Bojesen and collaborators, studying a group of 70 patients, supported the concept that CAGn polymorphism affects the phenotype of KS [68]. However, in this cohort, the CAGn repeats influenced height, arm span, total cholesterol, hemoglobin, and red blood cell count of KS patients, but not the response to TRT. Although testosterone might potentially affect metabolism through several mechanisms [69-72], TRT in KS 
does not seem directly affect glucose metabolism.

\section{Diagnostic and therapeutic perspectives}

Although KS patients are more insulin resistant and have an increased risk of developing MS and T2D, they are not listed among groups requiring a more frequent screening for metabolic impairment. Since T2D severely impacts mortality in KS and current standards of TRT failed to prove effective in this respect, an open issue remains on how to prevent or treat diabetes in KS patients. Specifically, no information is available within current guidelines regarding a particular strategy to be used in the prevention of diabetes or its complication in this particular group of patients [73]. In contrast, it is suggested that in any individual older than 45 years and with a condition of IR, such as polycystic ovary syndrome, severe obesity or acanthosis nigricans, should be tested for diabetes. We propose to add $\mathrm{KS}$ as a condition requiring early screening, maybe even earlier than 45 years, given the early onset of T2D in KS patients.

Counseling from an early age regarding a healthy diet and regular exercise is imperative for KS patients. As suggested by Davis et al [74], a screening for dyslipidemia with a fasting lipid panel at age 9 to 11 years and after puberty is completed (or sooner if additional risk factors are present) could be a good strategy to recognize MS or its features as soon as possible. This assessment needs to be repeated after puberty, and it is necessary to consider KS patients at highrisk of developing MS and T2D throughout their life.

In KS patients with MS or prediabetes, a Diabetes Prevention Program (DPP) should be considered. DPP, consistent in lifestyle changes such as nutritional suggestions (e.g. reducing caloric intake and increasing consumption of food high in monounsaturated fats), and physical activity (exercise prescriptions designed to prevent diabetes are based on aerobic activity and may include resistance training) has provided the strongest evidence for diabetes prevention in the general population $[75,76]$. Moreover, the use of metformin was effective in reducing the risk of diabetes by one third in individuals at high-risk for the disease [76]. Although solid data regarding 
patients with KS are lacking, the use of metformin in these patients might be equally effective.

When a diagnosis of T2D has been made, lifestyle management exerts a pivotal role in diabetes care with the latest guidelines including diabetes self-management education and support (DSMES), medical nutrition therapy (MNT), physical activity intensification, smoking cessation counseling, and psychosocial care [77]. In particular, considering the associated neuropsychological and behavior disorders described in KS, the multidisciplinary management of this aspect is an important factor that needs to be considered in the management of T2D in KS. Considering the well-known cardiovascular alterations [18,28], before starting physical activity a cardiovascular assessment is required, as elsewhere described [18].

No solid evidence is available for which drug is most appropriate for the treatment of diabetes or its complications in KS patients. However, given the fact that fat accumulation and distribution seems to plays a pivotal role in triggering metabolic abnormalities, drugs targeting body fat should be preferred. Although few data are available on the effect of hypoglycemic agents in KS, some drugs appear to be preferential $[42,62]$. In particular, metformin and GLP-1 receptor agonists should be the preferred drugs to use in KS patients with diabetes. Finally, the few data available suggest that KS patients with diabetes are not easily controlled by insulin treatment [56], therefore prevention strategies should be aggressive to delay the use of insulin. Future research should directly address the issue to provide evidence regarding the best approach for patients with KS and diabetes.

\section{Conclusions}

$\mathrm{KS}$ is described by a vicious circle and network of complex interactions that establish health complications of patients (Figure 1). Chromosomal abnormalities, influence body composition, causing an increase in body fat (especially intra-abdominal fat), the onset of IR and a related deterioration of carbohydrate metabolism leading to diabetes, but also induce the reduction of androgen secretion. Furthermore, IR aggravates hypogonadism [33] via a direct effect to further 
exaggerate the dysfunction of testosterone production by the Leydig cell [78]. In KS, TRT does not appear to change the prevalence of MS or to improve indices of IR, suggesting that more complex and unclear mechanisms sustain the link between KS and MS [40]. An early diagnosis and tailored intervention strategy seem mandatory in patients with KS, and should be aimed at targeting excessive visceral fat deposition.

\section{Compliance with ethical standards}

Conflict of interest: Dr. Salzano receives research grant support from Cardiopath. The remaining author declares that they have no conflict of interest.

Ethical approval: This article does not contain any studies with human participants or animals performed by any of the authors. 
Table I. Studies evaluating metabolic syndrome and insulin resistance in Klinefelter syndrome

$\begin{array}{llll}\text { Author, year (ref) } & \text { Pts } & \begin{array}{c}\text { Criteria used for } \\ \text { diagnosis of IR or MS }\end{array} & \text { Findings }\end{array}$

\section{A. Adult population}

A1.Insulin resistance

Pei D, 1998 [27]

Yesilova Z, 2005 [26]

Bardsley MZ, 2011 [37]

A2. Metabolic Syndrome

Bojesen A, 2006 [24]

Ishikawa T, 2008 [25]

Pasquali D, 2013 [28]

7 the total area under the curve (AUC) and the incremental AUC of serum insulin concentrations in response to a 75 -g oral glucose load, and the insulin suppression test

13 hyperinsulinemic euglycemic clamp

HOMA

89

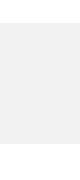
IR prevalence: $39 \%$

IR prevalence: $24 \%$ HOMA $>2.5$ $9.3 \%$ had fasting insulin levels $>20$ $\mathrm{IU} / \mathrm{mL}$

decreased insulin sensitivity and elevated fasting insulin in $\mathrm{KS}$

\section{Plasma glucose inversely related to $\mathrm{T}$} levels
$\mathrm{T}$ as an independent determinant of whole-body glucose disposal rate with hyperinsulinemic euglycemic clamp
Jiang-Feng M, 2012 [62]

39

60

revised NCEP/ATP III

criteria in Japan

(all criteria for MS

diagnosis were present except for BP and FBG).

NCEP/ATP III criteri
(all criteria for MS diagnosis were present except for BP) IDF criteria

69

NCEP/ATP III criteria (18 KS pts had increased waist circumference, 16 had impaired fasting glucose, 3 had diabetes mellitus, 12 had elevated triglycerides, 13 had decreased HDL cholesterol, and 4 had high diastolic blood pressure)
MS prevalence: $47 \%$ in $\mathrm{KS}(46 \%$ in untreated KS vs $49 \%$ in treated $\mathrm{KS}$ ) vs

$10 \%$ in controls MS prevalence $34 \%$ in KS vs. $22 \%$ in controls

MS prevalence: $30.8 \%$ before $\mathrm{T}$ treatment, $38.5 \%$ after $\mathrm{T}$ treatment for a median duration of 4 years in $\mathrm{KS}$ vs $15 \%$ and $20 \%$ respectively before and after $\mathrm{T}$ therapy in controls

MS prevalence: $49 \%$ in $\mathrm{KS}(47 \%$ untreated vs $50 \%$ treated) vs $10 \%$ in controls
T therapy did not affect IR (IM T injections [20 pts], oral T undecanoate [14 pts], and mesterolon [1 pt])

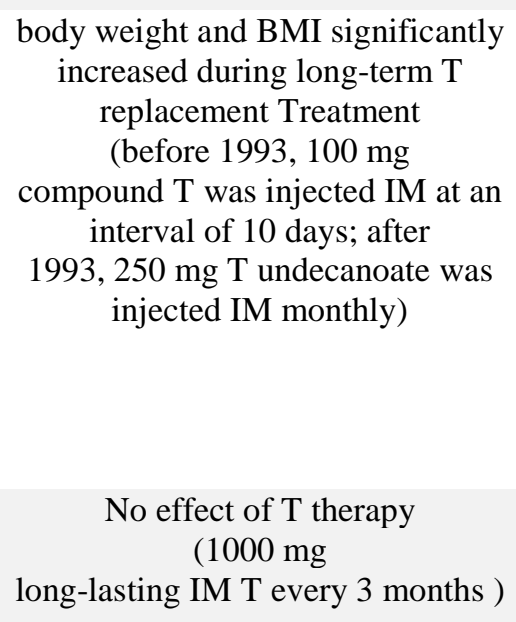
increased during long-term $\mathrm{T}$ replacement Treatment (before 1993, $100 \mathrm{mg}$ compound T was injected IM at an interval of 10 days; after

1993, $250 \mathrm{mg}$ T undecanoate was injected IM monthly)
No effect of T therapy (1000 mg

long-lasting IM T every 3 months )

\section{B.Pediatric population}




\begin{tabular}{|c|c|c|c|c|}
\hline Bardsley MZ, 2011 [37] & 89 & $\begin{array}{l}\text { adaptation of NCEP/ATP } \\
\text { III for pediatric use } \\
65 \% \text { of KS pts had } \\
\text { decreased HDL levels, } \\
15 \% \text { had elevated TG } \\
\text { levels, and } 49 \% \text { had a WC } \\
>75 \text { percentile. None had } \\
\text { elevated BP or FBG. }\end{array}$ & $\begin{array}{l}36 \% \text { with } \geq 1 \mathrm{MS} \\
\text { feature } \\
8 \% \text { with } \geq 3 \mathrm{MS} \\
\text { feature }\end{array}$ & - \\
\hline Davis S, 2016 [38] & $\begin{array}{l}93 \\
\text { pre- } \\
\text { puber } \\
\text { tal }\end{array}$ & $\begin{array}{l}\text { adaptation of NCEP/ATP } \\
\text { III for pediatric use }\end{array}$ & $\begin{array}{c}80 \% \text { with } \geq 1 \mathrm{MS} \\
\text { feature } \\
11 \% \text { with } \geq 3 \mathrm{MS} \\
\text { features }\end{array}$ & $\begin{array}{c}\text { No relationship } \\
\text { between } \mathrm{T} \text { and MS }\end{array}$ \\
\hline Davis S, 2017 [39] & $\begin{array}{l}93 \\
\text { pre- } \\
\text { puber } \\
\text { tal }\end{array}$ & $\begin{array}{l}\text { adaptation of NCEP/ATP } \\
\text { III for pediatric use }\end{array}$ & $\begin{array}{c}80 \% \text { with } \geq 1 \mathrm{MS} \\
\text { feature } \\
11 \% \text { with } \geq 3 \mathrm{MS} \\
\text { features }\end{array}$ & $\begin{array}{l}\text { T therapy had a modest improvement } \\
\text { on features of MS and body } \\
\text { composition, more expressed in the } \\
\text { subgroup of patients who remained } \\
\text { prepubertal throughout the study } \\
\text { despite a decline in HDL and little } \\
\text { bone age advancement. } \\
\text { (Oral oxandrolone (Ox) } 0.06 \\
\text { mg/kg/die or placebo) }\end{array}$ \\
\hline
\end{tabular}

T: Testosterone; MS: metabolic syndrome; KS: Klinefelter Syndrome; IR: Insulin-Resistance; HOMA: homeostatic model assessment: BP; blood pressure, FBG, fasting blood glucose; WC, waist circumference; Pts: patients; IM: intramuscular. National Cholesterol Education Program - Adult Treatment Panel III (NCEP- ATP III) criteria [20]: 1) increased waist circumference (i.e. in Caucasian males $>102 \mathrm{~cm}$, in Japan males $>85 \mathrm{~cm}$ females $>88 \mathrm{~cm}$ ); 2) high plasma triglycerides ( $>150 \mathrm{mg} / \mathrm{dl} ; 3)$ low HDL-cholesterol ( $<40$ in men and $<50 \mathrm{mg} / \mathrm{dl}$ in women); 4) elevated systolic or diastolic blood pressure (>135 or $85 \mathrm{mmHg}$, respectively); 5) impaired fasting glucose (>110 mg/dl). 3 or more of the criteria needed. International Diabetes Federation (IDF) criteria [22]: central obesity with waist circumference $>90$ $\mathrm{cm}$, plus any two of four additional factors include triglyceride $>150 \mathrm{mg} / \mathrm{dL}$, highdensity lipoprotein (HDL)-cholesterol $<40 \mathrm{mg} / \mathrm{dL}$ (or treatment for dyslipidemia), systolic blood pressure $>130 \mathrm{~mm} \mathrm{Hg}$ or diastolic blood pressure $>85 \mathrm{~mm}$ $\mathrm{Hg}$ (or treatment of previous hypertension), and fasting plasma glucose $>100 \mathrm{mg} / \mathrm{dL}$ (or previously diagnosed type 2 diabetes). Adaptation of NCEP/ATP III for pediatric use [23]: 1) central obesity with waist circumference $>75$ th percentile for age and gender, 2) high plasma triglycerides $(>97 \mathrm{mg} / \mathrm{dl}$; 3) low HDL-cholesterol $(<50 \mathrm{mg} / \mathrm{dL}$, boys aged 15-19 years $<45)$; 4) elevated systolic or diastolic blood pressure (>90th percentile for age, gender, and height); 5) impaired fasting glucose $(>110 \mathrm{mg} / \mathrm{dl})$. 
Table II. Diabetes Mellitus in Klinefelter Syndrome

\begin{tabular}{|c|c|c|c|}
\hline Author, year (ref) & Patients & T2D Prevalence & $\begin{array}{c}\text { Effect of } T \text { replacement therapy } \\
\text { (type of } T \text { therapy) }\end{array}$ \\
\hline Forbes $A P, 1963[61]$ & 41 & $15 \%$ & - \\
\hline Nielsen J, 1966 [60] & 25 & $32 \%$ & \\
\hline Jackson IM, 1966 [58] & 8 & $12 \%$ & - \\
\hline Becker KL, 1966 [59] & 50 & $10 \%$ & - \\
\hline Zuppinger K, 1967 [63] & 24 & $25 \%$ & \\
\hline Nielsen J, 1969 [56] & 31 & $\begin{array}{l}\text { 39\%: specifically } 20.8 \% \text { in patients with } \\
47, \mathrm{XXY} \text { karyotype, } 100 \% \text { with other } \\
\text { karyotypes ( } 4 \text { patients with } 46, \mathrm{XY} / 47, \mathrm{XXY} \\
\text { chimera and } 3 \text { patients with } 49, \mathrm{XXXXY)}\end{array}$ & - \\
\hline Sagara MN, 1986 [64] & - & $3,9 \%$ & - \\
\hline Takeushi Y, 1999 [53] & Rev & $\begin{array}{c}15 \%-50 \% \text { in Western countries } \\
3.9 \%-4.1 \% \text { in Japan }\end{array}$ & - \\
\hline Ota K, 2002 [65] & 895 & $6.5 \%$ & $\begin{array}{c}\text { No effect } \\
\text { (type of T treatment not reported) }\end{array}$ \\
\hline Lichiardopol C, 2004 [66] & 31 & $\begin{array}{c}16 \% \text { of KS have Prediabetes } \\
0 \% \text { have T2D }\end{array}$ & - \\
\hline Bojesen A, 2004 [14] & 781 & $\begin{array}{l}\text { HR: T1D 2.21: T2D } 3.71 \text {. } \\
\text { Mortality for DM } 1.64\end{array}$ & - \\
\hline Swerdlow AJ, 2005 [15] & 4806 & $\begin{array}{l}\text { T2D cause-specific MR: 7.07; } \\
\text { SMR:5.8; HR: } 1,6\end{array}$ & - \\
\hline Bojesen, A 2006 [24] & 70 & $\begin{array}{c}10 \%(9 \% \text { in untreated } \mathrm{KS} \text { vs } 11 \% \text { in treated } \\
\mathrm{KS})\end{array}$ & $\begin{array}{c}\text { No effect } \\
\text { (intramuscular T injections [20 pts], } \\
\text { oral testosterone undecanoate [14 } \\
\text { pts], and mesterolon [1 pt]) }\end{array}$ \\
\hline Jiang-Feng M, 2012 [62] & 39 & $\begin{array}{l}20.5 \% \text {; specifically } \\
12.5 \% \text { in } 47, \mathrm{XXY} \text { and } 57.1 \% \text { in pts with other } \\
\text { atypical karyotypes (46XY/47XXY } \\
\text { chimera and others). }\end{array}$ & $\begin{array}{c}\text { Body weight and BMI significantly } \\
\text { increased during } \\
\text { long-term TRT } \\
\text { (before 1993, } 100 \mathrm{mg} \\
\text { compound T was injected IM at an } \\
\text { interval of } 10 \text { days; after } \\
\text { 1993, } 250 \text { mg T undecanoate was } \\
\text { injected IM monthly) }\end{array}$ \\
\hline Pasquali D, 2013 [28] & 69 & $8 \%(9 \%$ in untreated $\mathrm{KS}$ and $6 \%$ in treated $\mathrm{KS})$ & $\begin{array}{c}\text { No effect } \\
(1000 \mathrm{mg} \\
\text { long-lasting intramuscular T every } 3 \\
\text { months) }\end{array}$ \\
\hline Han SJ, 2016 [43] & 376 & $\begin{array}{c}\text { Prediabetes: } 26 \% \text {; specifically, } 19.8 \% \text { in non- } \\
\text { obese pts and } 38 \% \text { in obese patients }(\mathrm{p}<.05) \\
\text { T2D: } 12.8 \% \text {; specifically, } 11.6 \% \text { in non-obese } \\
\text { pts and } 14.3 \% \text { in obese pts }\end{array}$ & - \\
\hline
\end{tabular}

Rev: review; T: Testosterone; T2D: type 2 Diabetes Mellitus; KS: Klinefelter Syndrome; T1D: type 1

Diabetes Mellitus; MR: mortality ratio; SMR: standard mortality ratio; HR: Hazard Ratio: pts: patients 


\section{Figure legends.}

Fig1. Vicious circle and network of complex interactions in Klinefelter syndrome.

Klinefelter Syndrome induces hypogonadism and influences body composition, causing an increase in body fat (especially intra-abdominal fat), inducing IR which, in turn, aggravates the hypogonadism via a direct effect on Leydig cell production of residual testosterone. However, testosterone therapy does not appear to change the prevalence of MS or T2D nor improve indices of IR. The mechanisms active in the general population (panel A) or in the patients with KS (panel B) are depicted. Green circles represent the general population. Blue circles represent KS patients. Green or blue arrows indicate mechanisms active in the general population or in KS patients, respectively. The arrows are in continuous or dashed format to indicate an action toward an increase or a decrease of the target parameter, respectively.

\section{References.}

1. Klinefelter, H.F., Reifenstein, E.C., Albright, F.: Syndrome characterized by gynaecomastia, aspermatogenesis without a-Leydigism, and increased excretion of follicle stimulating hormone. J Clin Endocrinol 2(11), 615-627 (1942).

2. Morris, J.K., Alberman, E., Scott, C., Jacobs, P.: Is the prevalence of Klinefelter syndrome increasing? Eur J Hum Genet 16(2), 163-170 (2008). doi:10.1038/sj.ejhg.5201956

3. Bojesen, A., Juul, S., Gravholt, C.H.: Prenatal and postnatal prevalence of Klinefelter syndrome: a national registry study. J Clin Endocrinol Metab 88(2), 622-626 (2003). doi:10.1210/jc.2002-021491

4. Forti, G., Corona, G., Vignozzi, L., Krausz, C., Maggi, M.: Klinefelter's syndrome: a clinical and therapeutical update. Sex Dev 4(4-5), 249-258 (2010). doi:10.1159/000316604

5. Ropke, A., Tuttelmann, F.: MECHANISMS IN ENDOCRINOLOGY: Aberrations of the X chromosome as cause of male infertility. Eur J Endocrinol 177(5), R249-R259 (2017). doi:10.1530/EJE-17-0246

6. Albuquerque, E.V., Scalco, R.C., Jorge, A.A.: MANAGEMENT OF ENDOCRINE DISEASE: Diagnostic and therapeutic approach of tall stature. Eur J Endocrinol 176(6), R339-R353 (2017). doi:10.1530/EJE-16-1054

7. Sansone, A., Romanelli, F., Sansone, M., Lenzi, A., Di Luigi, L.: Gynecomastia and hormones. Endocrine 55(1), 37-44 (2017). doi:10.1007/s12020-016-0975-9

8. Rohayem, J., Luberto, A., Nieschlag, E., Zitzmann, M., Kliesch, S.: Delayed treatment of undescended testes may promote hypogonadism and infertility. Endocrine 55(3), 914-924 (2017). doi:10.1007/s12020-016-1178-0

9. Sansone, A., Romanelli, F., Gianfrilli, D., Lenzi, A.: Endocrine evaluation of erectile dysfunction. Endocrine 46(3), 423-430 (2014). doi:10.1007/s12020-014-0254-6

10. Radicioni, A.F., De Marco, E., Gianfrilli, D., Granato, S., Gandini, L., Isidori, A.M., Lenzi, A.: Strategies and advantages of early diagnosis in Klinefelter's syndrome. Mol Hum Reprod 16(6), 434-440 (2010). doi:10.1093/molehr/gaq027

11. Lanfranco, F., Kamischke, A., Zitzmann, M., Nieschlag, E.: Klinefelter's syndrome. Lancet 364(9430), 273-283 (2004). doi:10.1016/S0140-6736(04)16678-6

12. Liberato, D., Granato, S., Grimaldi, D., Rossi, F.M., Tahani, N., Gianfrilli, D., Anzuini, A., Lenzi, A., Cavaggioni, G., Radicioni, A.F.: Fluid intelligence, traits of personality and personality disorders in a cohort of adult KS patients with the classic 47, XXY karyotype. $\mathrm{J}$ Endocrinol Invest 40(11), 1191-1199 (2017). doi:10.1007/s40618-017-0674-2

13. Bojesen, A., Juul, S., Birkebaek, N.H., Gravholt, C.H.: Morbidity in Klinefelter syndrome: a Danish register study based on hospital discharge diagnoses. J Clin Endocrinol Metab 91(4), 1254-1260 (2006). doi:10.1210/jc.2005-0697 
14. Bojesen, A., Juul, S., Birkebaek, N., Gravholt, C.H.: Increased mortality in Klinefelter syndrome. J Clin Endocrinol Metab 89(8), 3830-3834 (2004). doi:10.1210/jc.2004-0777

15. Swerdlow, A.J., Higgins, C.D., Schoemaker, M.J., Wright, A.F., Jacobs, P.A., United Kingdom Clinical Cytogenetics, G.: Mortality in patients with Klinefelter syndrome in Britain: a cohort study. J Clin Endocrinol Metab 90(12), 6516-6522 (2005). doi:10.1210/jc.2005-1077

16. Bojesen, A., Gravholt, C.H.: Morbidity and mortality in Klinefelter syndrome (47,XXY). Acta Paediatr 100(6), 807-813 (2011). doi:10.1111/j.1651-2227.2011.02274.x

17. Price, W.H., Clayton, J.F., Collyer, S., de Mey, R.: Mortality ratios and life expectancy in X chromatin positive males. J Epidemiol Community Health 39(1), 33-38 (1985).

18. Salzano, A., Arcopinto, M., Marra, A.M., Bobbio, E., Esposito, D., Accardo, G., Giallauria, F., Bossone, E., Vigorito, C., Lenzi, A., Pasquali, D., Isidori, A.M., Cittadini, A.: Klinefelter syndrome, cardiovascular system, and thromboembolic disease: review of literature and clinical perspectives. Eur J Endocrinol 175(1), R27-40 (2016). doi:10.1530/EJE-15-1025

19. Calogero, A.E., Giagulli, V.A., Mongioi, L.M., Triggiani, V., Radicioni, A.F., Jannini, E.A., Pasquali, D., Klinefelter Italia, N.G.: Klinefelter syndrome: cardiovascular abnormalities and metabolic disorders. J Endocrinol Invest 40(7), 705-712 (2017). doi:10.1007/s40618017-0619-9

20. National Cholesterol Education Program Expert Panel on Detection, E., Treatment of High Blood Cholesterol in, A.: Third Report of the National Cholesterol Education Program (NCEP) Expert Panel on Detection, Evaluation, and Treatment of High Blood Cholesterol in Adults (Adult Treatment Panel III) final report. Circulation 106(25), 3143-3421 (2002).

21. Ford, E.S.: Prevalence of the metabolic syndrome defined by the International Diabetes Federation among adults in the U.S. Diabetes Care 28(11), 2745-2749 (2005).

22. Alberti, K.G., Eckel, R.H., Grundy, S.M., Zimmet, P.Z., Cleeman, J.I., Donato, K.A., Fruchart, J.C., James, W.P., Loria, C.M., Smith, S.C., Jr., International Diabetes Federation Task Force on, E., Prevention, Hational Heart, L., Blood, I., American Heart, A., World Heart, F., International Atherosclerosis, S., International Association for the Study of, O.:

Harmonizing the metabolic syndrome: a joint interim statement of the International Diabetes Federation Task Force on Epidemiology and Prevention; National Heart, Lung, and Blood Institute; American Heart Association; World Heart Federation; International Atherosclerosis Society; and International Association for the Study of Obesity. Circulation 120(16), 1640-1645 (2009). doi:10.1161/CIRCULATIONAHA.109.192644

23. de Ferranti, S.D., Gauvreau, K., Ludwig, D.S., Neufeld, E.J., Newburger, J.W., Rifai, N.: Prevalence of the metabolic syndrome in American adolescents: findings from the Third National Health and Nutrition Examination Survey. Circulation 110(16), 2494-2497 (2004). doi:10.1161/01.CIR.0000145117.40114.C7

24. Bojesen, A., Kristensen, K., Birkebaek, N.H., Fedder, J., Mosekilde, L., Bennett, P., Laurberg, P., Frystyk, J., Flyvbjerg, A., Christiansen, J.S., Gravholt, C.H.: The metabolic syndrome is frequent in Klinefelter's syndrome and is associated with abdominal obesity and hypogonadism. Diabetes Care 29(7), 1591-1598 (2006). doi:10.2337/dc06-0145

25. Ishikawa, T., Yamaguchi, K., Kondo, Y., Takenaka, A., Fujisawa, M.: Metabolic syndrome in men with Klinefelter's syndrome. Urology 71(6), 1109-1113 (2008). doi:10.1016/j.urology.2008.01.051

26. Yesilova, Z., Oktenli, C., Sanisoglu, S.Y., Musabak, U., Cakir, E., Ozata, M., Dagalp, K.: Evaluation of insulin sensitivity in patients with Klinefelter's syndrome: a hyperinsulinemic euglycemic clamp study. Endocrine 27(1), 11-15 (2005). doi:10.1385/ENDO:27:1:011

27. Pei, D., Sheu, W.H., Jeng, C.Y., Liao, W.K., Fuh, M.M.: Insulin resistance in patients with Klinefelter's syndrome and idiopathic gonadotropin deficiency. J Formos Med Assoc 97(8), 534-540 (1998).

28. Pasquali, D., Arcopinto, M., Renzullo, A., Rotondi, M., Accardo, G., Salzano, A., Esposito, D., Saldamarco, L., Isidori, A.M., Marra, A.M., Ruvolo, A., Napoli, R., Bossone, E., Lenzi, A., 
Baliga, R.R., Sacca, L., Cittadini, A.: Cardiovascular abnormalities in Klinefelter syndrome. Int J Cardiol 168(2), 754-759 (2013). doi:10.1016/j.ijcard.2012.09.215

29. Brand, J.S., van der Tweel, I., Grobbee, D.E., Emmelot-Vonk, M.H., van der Schouw, Y.T.: Testosterone, sex hormone-binding globulin and the metabolic syndrome: a systematic review and meta-analysis of observational studies. Int J Epidemiol 40(1), 189-207 (2011). doi:10.1093/ije/dyq158

30. Kelly, D.M., Akhtar, S., Sellers, D.J., Muraleedharan, V., Channer, K.S., Jones, T.H.: Testosterone differentially regulates targets of lipid and glucose metabolism in liver, muscle and adipose tissues of the testicular feminised mouse. Endocrine 54(2), 504-515 (2016). doi:10.1007/s12020-016-1019-1

31. Mitsuhashi, K., Senmaru, T., Fukuda, T., Yamazaki, M., Shinomiya, K., Ueno, M., Kinoshita, S., Kitawaki, J., Katsuyama, M., Tsujikawa, M., Obayashi, H., Nakamura, N., Fukui, M.: Testosterone stimulates glucose uptake and GLUT4 translocation through LKB1/AMPK signaling in 3T3-L1 adipocytes. Endocrine 51(1), 174-184 (2016). doi:10.1007/s12020-0150666-y

32. Camacho, E.M., Huhtaniemi, I.T., O'Neill, T.W., Finn, J.D., Pye, S.R., Lee, D.M., Tajar, A., Bartfai, G., Boonen, S., Casanueva, F.F., Forti, G., Giwercman, A., Han, T.S., Kula, K., Keevil, B., Lean, M.E., Pendleton, N., Punab, M., Vanderschueren, D., Wu, F.C., Group, E.: Age-associated changes in hypothalamic-pituitary-testicular function in middle-aged and older men are modified by weight change and lifestyle factors: longitudinal results from the European Male Ageing Study. Eur J Endocrinol 168(3), 445-455 (2013). doi:10.1530/EJE12-0890

33. Landry, D., Pare, A., Jean, S., Martin, L.J.: Adiponectin influences progesterone production from MA-10 Leydig cells in a dose-dependent manner. Endocrine 48(3), 957-967 (2015). doi:10.1007/s12020-014-0456-y

34. Isidori, A.M., Balercia, G., Calogero, A.E., Corona, G., Ferlin, A., Francavilla, S., Santi, D., Maggi, M.: Outcomes of androgen replacement therapy in adult male hypogonadism: recommendations from the Italian society of endocrinology. J Endocrinol Invest 38(1), 103112 (2015). doi:10.1007/s40618-014-0155-9

35. Bekaert, M., Van Nieuwenhove, Y., Calders, P., Cuvelier, C.A., Batens, A.H., Kaufman, J.M., Ouwens, D.M., Ruige, J.B.: Determinants of testosterone levels in human male obesity. Endocrine 50(1), 202-211 (2015). doi:10.1007/s12020-015-0563-4

36. Gies, I., Unuane, D., Velkeniers, B., De Schepper, J.: Management of Klinefelter syndrome during transition. Eur J Endocrinol 171(2), R67-77 (2014). doi:10.1530/EJE-14-0213

37. Bardsley, M.Z., Falkner, B., Kowal, K., Ross, J.L.: Insulin resistance and metabolic syndrome in prepubertal boys with Klinefelter syndrome. Acta Paediatr 100(6), 866-870 (2011). doi:10.1111/j.1651-2227.2011.02161.x

38. Davis, S., Lahlou, N., Bardsley, M., Temple, M.C., Kowal, K., Pyle, L., Zeitler, P., Ross, J.: Gonadal function is associated with cardiometabolic health in pre-pubertal boys with Klinefelter syndrome. Andrology 4(6), 1169-1177 (2016). doi:10.1111/andr.12275

39. Davis, S.M., Cox-Martin, M.G., Bardsley, M.Z., Kowal, K., Zeitler, P.S., Ross, J.L.: Effects of Oxandrolone on Cardiometabolic Health in Boys With Klinefelter Syndrome: A Randomized Controlled Trial. J Clin Endocrinol Metab 102(1), 176-184 (2017). doi:10.1210/jc.2016-2904

40. Iwatsuki, S., Sasaki, S., Taguchi, K., Hamakawa, T., Mizuno, K., Okada, A., Kubota, Y., Umemoto, Y., Hayashi, Y., Yasui, T.: Effect of obesity on sperm retrieval outcome and reproductive hormone levels in Japanese azoospermic men with and without Klinefelter syndrome. Andrology 5(1), 82-86 (2017). doi:10.1111/andr.12281

41. Aksglaede, L., Molgaard, C., Skakkebaek, N.E., Juul, A.: Normal bone mineral content but unfavourable muscle/fat ratio in Klinefelter syndrome. Arch Dis Child 93(1), 30-34 (2008). doi:10.1136/adc.2007.120675 
42. Giagulli, V.A., Carbone, M.D., Ramunni, M.I., Licchelli, B., De Pergola, G., Sabba, C., Guastamacchia, E., Triggiani, V.: Adding liraglutide to lifestyle changes, metformin and testosterone therapy boosts erectile function in diabetic obese men with overt hypogonadism. Andrology 3(6), 1094-1103 (2015). doi:10.1111/andr.12099

43. Han, S.J., Kim, K.S., Kim, W., Kim, J.H., Lee, Y.H., Nam, J.S., Seo, J.A., Kim, B.K., Lee, J., Chung, J.O., Kim, M.H., Sohn, T.S., Choi, H.S., Hong, S.B., Chung, Y.S.: Obesity and Hyperglycemia in Korean Men with Klinefelter Syndrome: The Korean Endocrine Society Registry. Endocrinol Metab (Seoul) 31(4), 598-603 (2016). doi:10.3803/EnM.2016.31.4.598

44. Aksglaede, L., Link, K., Giwercman, A., Jorgensen, N., Skakkebaek, N.E., Juul, A.: 47,XXY Klinefelter syndrome: clinical characteristics and age-specific recommendations for medical management. Am J Med Genet C Semin Med Genet 163C(1), 55-63 (2013). doi:10.1002/ajmg.c.31349

45. Arcopinto, M., Cella, C.A., Wesolowski, R., Salzano, A., Bossone, E., Cittadini, A., Baliga, R.R.: Primary prevention of cancer-related thrombosis: special focus on ambulatory patients. Int J Cardiol 173(3), 583-584 (2014). doi:10.1016/j.ijcard.2014.03.109

46. Salzano, A., Demelo-Rodriguez, P., Marra, A.M., Proietti, M.: A Focused Review of Gender Differences in Antithrombotic Therapy. Curr Med Chem 24(24), 2576-2588 (2017). doi:10.2174/0929867323666161029223512

47. Rotondi, M., Coperchini, F., Renzullo, A., Accardo, G., Esposito, D., Groppelli, G., Magri, F., Cittadini, A., Isidori, A.M., Chiovato, L., Pasquali, D.: High circulating levels of CCL2 in patients with Klinefelter's syndrome. Clin Endocrinol (Oxf) 80(3), 465-467 (2014). doi:10.1111/cen.12245

48. Belli, S., Santi, D., Leoni, E., Dall'Olio, E., Fanelli, F., Mezzullo, M., Pelusi, C., Roli, L., Tagliavini, S., Trenti, T., Granata, A.R., Pagotto, U., Pasquali, R., Rochira, V., Carani, C., Simoni, M.: Human chorionic gonadotropin stimulation gives evidence of differences in testicular steroidogenesis in Klinefelter syndrome, as assessed by liquid chromatographytandem mass spectrometry. Eur J Endocrinol 174(6), 801-811 (2016). doi:10.1530/EJE-151224

49. Andersen, N.H., Bojesen, A., Christiansen, J.S., Gravholt, C.H.: Glycemia, lipidemia and systolic left ventricular function evaluated by myocardial strain rate: a tissue Doppler echocardiographic study. Ultrasound Med Biol 34(1), 151-154 (2008). doi:10.1016/j.ultrasmedbio.2007.08.005

50. Daneman, D.: Type 1 diabetes. Lancet 367(9513), 847-858 (2006). doi:10.1016/S01406736(06)68341-4

51. Panimolle, F., Tiberti, C., Granato, S., Semeraro, A., Gianfrilli, D., Anzuini, A., Lenzi, A., Radicioni, A.: Screening of endocrine organ-specific humoral autoimmunity in 47,XXY Klinefelter's syndrome reveals a significant increase in diabetes-specific immunoreactivity in comparison with healthy control men. Endocrine 52(1), 157-164 (2016). doi:10.1007/s12020-015-0613-y

52. Langeron, L., Lamelin, P., Routier, G.: [Klinefelter syndrome and diabetes]. J Sci Med Lille 76(11), 440-444 (1958).

53. Takeuchi, Y., Murata, Y., Sintani, J., Masukawa, H., Nakamura, R., Oi, K., Kato, Y., Niinomi, M.: Klinefelter's syndrome accompanied by mixed connective tissue disease and diabetes mellitus. Intern Med 38(11), 875-881 (1999).

54. Milcou, S.M., Ionesco, B., Bucur, A.: [Glucide metabolism in Klinefelter's disease]. Rev Fr Endocrinol Clin 12(4), 305-314 (1971).

55. Esmann, V., Nielsen, J., Petersen, G.B.: A case of Klinefelter's syndrome with 48,XXXY and diabetes mellitus. Acta Med Scand 186(1-2), 27-33 (1969).

56. Nielsen, J., Johansen, K., Yde, H.: Frequency of diabetes mellitus in patients with Klinefelter's syndrome of different chromosome constitutions and the XYY syndrome. Plasma insulin 
and growth hormone level after a glucose load. J Clin Endocrinol Metab 29(8), 1062-1073 (1969). doi:10.1210/jcem-29-8-1062

57. Mirouze, J., Jaffiol, C., Bernard, C., Cartry, E.: [The prediabetes of Klinefelter's syndrome]. Diabete 14(2), 57-59 (1966).

58. Jackson, I.M., Buchanan, K.D., McKiddie, M.T., Prentice, C.R.: Carbohydrate metabolism in Klinefelter's syndrome. J Endocrinol 35(2), 169-172 (1966).

59. Becker, K.L., Hoffman, D.L., Underdahl, L.O., Mason, H.L.: Klinefelter's syndrome. Clinical and laboratory findings in 50 patients. Arch Intern Med 118(4), 314-321 (1966).

60. Nielsen, J.: Diabetes Mellitus in Parents of Patients with Klinefelter's Syndrome. Lancet 287, 1376 (1966).

61. Forbes, A.P., Engel, E.: The high incidence of diabetes mellitus in 41 patients with gonadal dysgenesis, and their close relatives. Metabolism 12, 428-439 (1963).

62. Jiang-Feng, M., Hong-Li, X., Xue-Yan, W., Min, N., Shuang-Yu, L., Hong-Ding, X., LiangMing, L.: Prevalence and risk factors of diabetes in patients with Klinefelter syndrome: a longitudinal observational study. Fertil Steril 98(5), 1331-1335 (2012). doi:10.1016/j.fertnstert.2012.07.1122

63. Zuppinger, K., Engel, E., Forbes, A.P., Mantooth, L., Claffey, J.: Klinefelter's syndrome, a clinical and cytogenetic study in twenty-four cases. Acta Endocrinol (Copenh) 54, Suppl 113:115+ (1967).

64. Sagara, M., Nakasono, M., Makino, I., Takebe, K.: Two cases of Klinefelter's syndrome associated with diabetes mellitus, and analysing the clinical features of all domestic reported cases. J Jpn Diab Soc 28(5), 677-686 (1986).

65. Ota, K., Suehiro, T., Ikeda, Y., Arii, K., Kumon, Y., Hashimoto, K.: Diabetes mellitus associated with Klinefelter's syndrome: a case report and review in Japan. Intern Med 41(10), 842-847 (2002).

66. Lichiardopol, C., Mota, M., Panus, C.: Metabolic changes in Klinefelter syndrome. Rom J Intern Med 42(2), 415-422 (2004).

67. Zitzmann, M., Bongers, R., Werler, S., Bogdanova, N., Wistuba, J., Kliesch, S., Gromoll, J., Tuttelmann, F.: Gene expression patterns in relation to the clinical phenotype in Klinefelter syndrome. J Clin Endocrinol Metab 100(3), E518-523 (2015). doi:10.1210/jc.2014-2780

68. Bojesen, A., Hertz, J.M., Gravholt, C.H.: Genotype and phenotype in Klinefelter syndrome impact of androgen receptor polymorphism and skewed X inactivation. Int J Androl 34(6 Pt 2), e642-648 (2011). doi:10.1111/j.1365-2605.2011.01223.x

69. Arcopinto, M., Salzano, A., Bossone, E., Ferrara, F., Bobbio, E., Sirico, D., Vriz, O., De Vincentiis, C., Matarazzo, M., Saldamarco, L., Sacca, F., Napoli, R., Iacoviello, M., Triggiani, V., Isidori, A.M., Vigorito, C., Isgaard, J., Cittadini, A.: Multiple hormone deficiencies in chronic heart failure. Int J Cardiol 184, 421-423 (2015). doi:10.1016/j.ijcard.2015.02.055

70. Arcopinto, M., Salzano, A., Isgaard, J., Cittadini, A.: Hormone replacement therapy in heart failure. Curr Opin Cardiol 30(3), 277-284 (2015). doi:10.1097/HCO.0000000000000166

71. Marra, A.M., Arcopinto, M., Bobbio, E., Salzano, A., Sacca, L., Cittadini, A.: An unusual case of dilated cardiomyopathy associated with partial hypopituitarism. Intern Emerg Med 7

Suppl 2, S85-87 (2012). doi:10.1007/s11739-011-0649-9

72. Salzano, A., Marra, A.M., Ferrara, F., Arcopinto, M., Bobbio, E., Valente, P., Polizzi, R., De Vincentiis, C., Matarazzo, M., Saldamarco, L., Sacca, F., Napoli, R., Monti, M.G., D'Assante, R., Isidori, A.M., Isgaard, J., Ferrara, N., Filardi, P.P., Perticone, F., Vigorito, C., Bossone, E., Cittadini, A., investigators, T.O.S.C.: Multiple hormone deficiency syndrome in heart failure with preserved ejection fraction. Int J Cardiol 225, 1-3 (2016). doi:10.1016/j.ijcard.2016.09.085

73. American Diabetes, A.: 2. Classification and Diagnosis of Diabetes. Diabetes Care 40(Suppl 1), S11-S24 (2017). doi:10.2337/dc17-S005 
74. Davis, S., Howell, S., Wilson, R., Tanda, T., Ross, J., Zeitler, P., Tartaglia, N.: Advances in the Interdisciplinary Care of Children with Klinefelter Syndrome. Adv Pediatr 63(1), 15-46 (2016). doi:10.1016/j.yapd.2016.04.020

75. American Diabetes, A.: 5. Prevention or Delay of Type 2 Diabetes: Standards of Medical Care in Diabetes-2018. Diabetes Care 41(Suppl 1), S51-S54 (2018). doi:10.2337/dc18-S005

76. Knowler, W.C., Barrett-Connor, E., Fowler, S.E., Hamman, R.F., Lachin, J.M., Walker, E.A., Nathan, D.M., Diabetes Prevention Program Research, G.: Reduction in the incidence of type 2 diabetes with lifestyle intervention or metformin. N Engl J Med 346(6), 393-403 (2002). doi:10.1056/NEJMoa012512

77. American Diabetes, A.: 4. Lifestyle Management: Standards of Medical Care in Diabetes-2018. Diabetes Care 41(Suppl 1), S38-S50 (2018). doi:10.2337/dc18-S004

78. Pitteloud, N., Hardin, M., Dwyer, A.A., Valassi, E., Yialamas, M., Elahi, D., Hayes, F.J.: Increasing insulin resistance is associated with a decrease in Leydig cell testosterone secretion in men. J Clin Endocrinol Metab 90(5), 2636-2641 (2005). doi:10.1210/jc.20042190 


\section{A. General population}

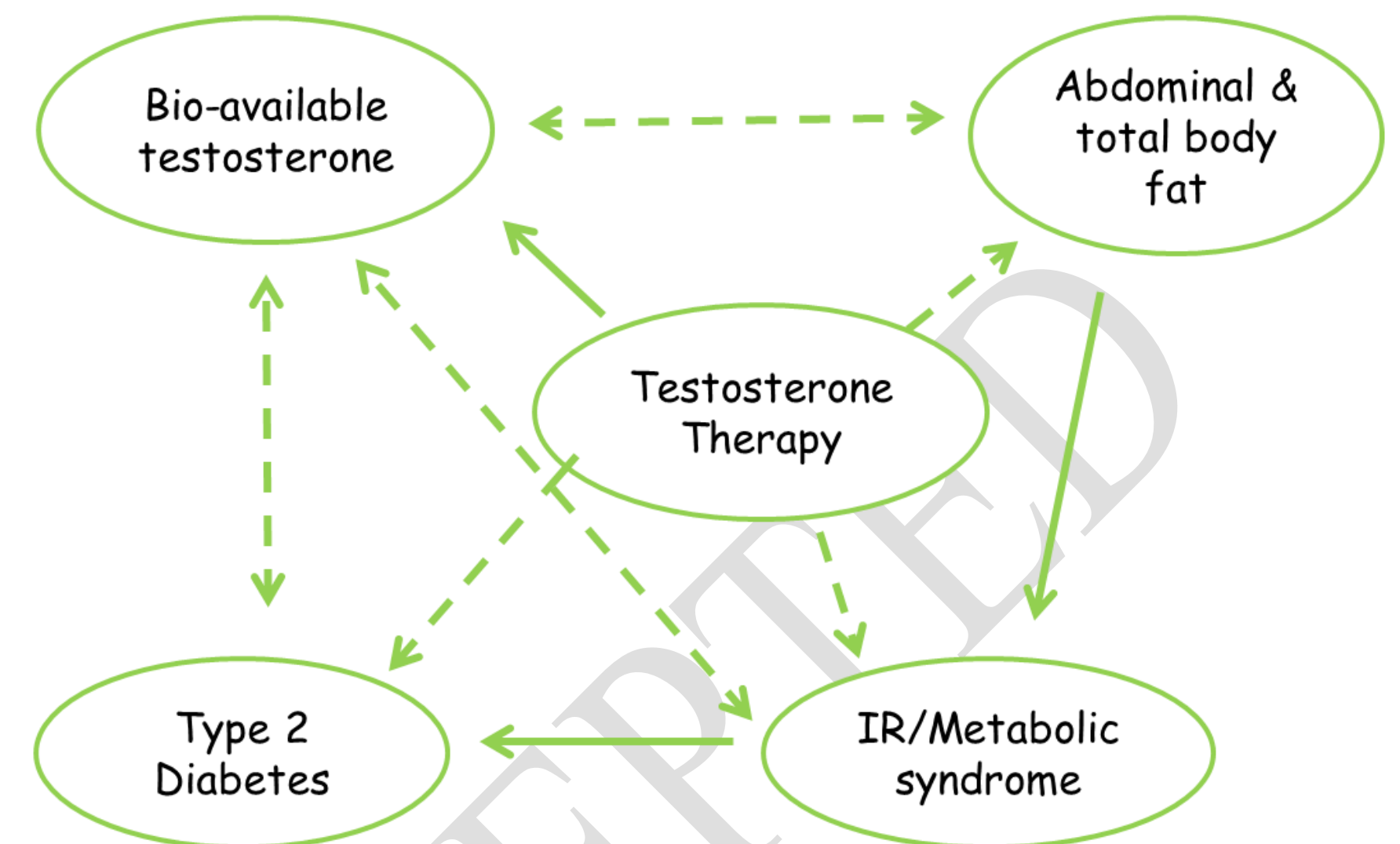

B. Klinefelter syndrome patients

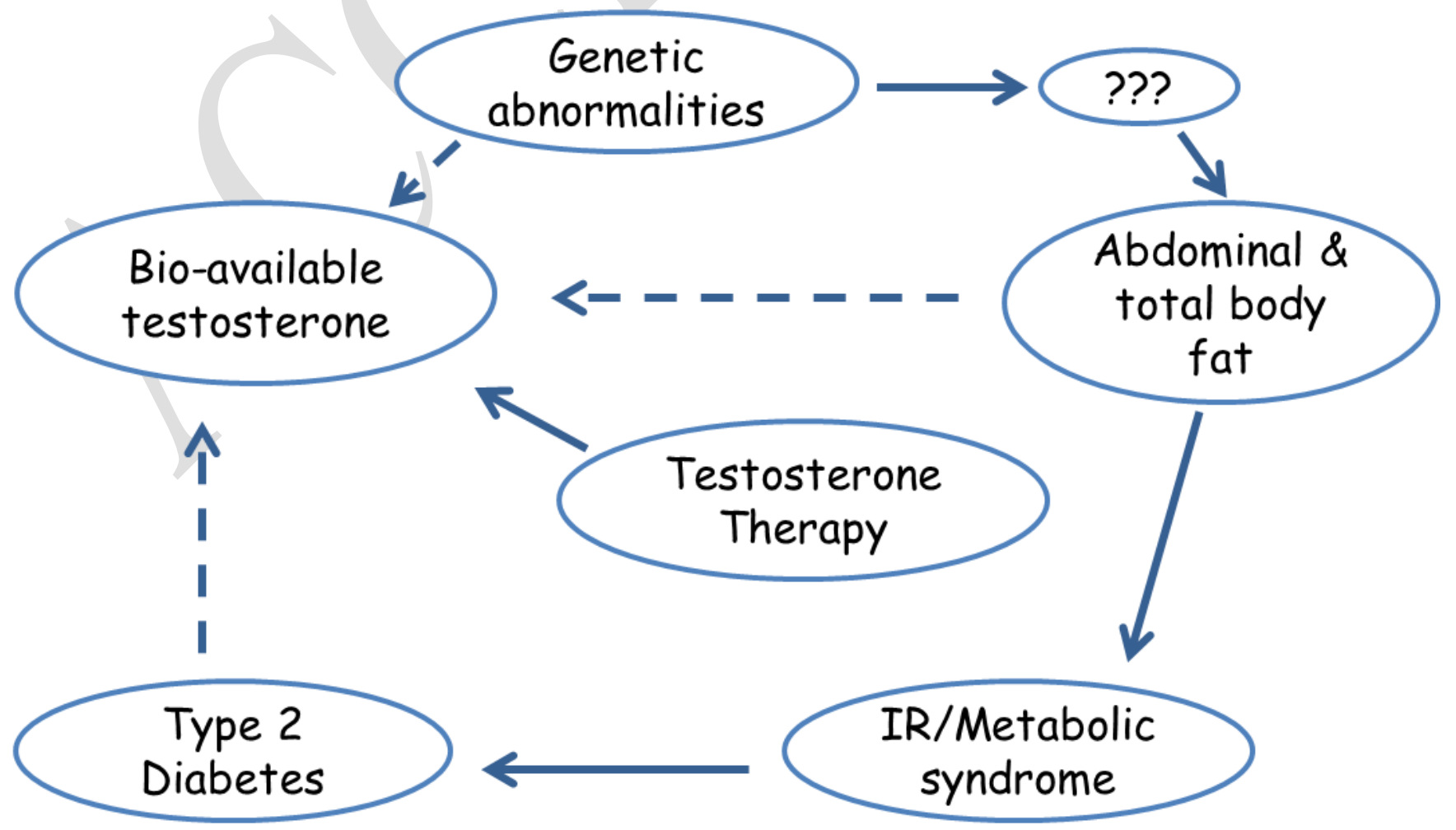

